\section{Age of Plant Material Influences Resistance of Some Prunus Rootstocks to Meloidogyne incognita}

\author{
Carolina Fernández ${ }^{1}$ and Jorge Pinochet ${ }^{2}$ \\ Departamento de Patología Vegetal, Institut de Recerca $i$ Tecnologia \\ Agroalimentàries, Carretera de Cabrils s/n 08348, Cabrils, Barcelona, Spain
}

Daniel Esmenjaud ${ }^{2}$

Laboratoire de Biologie des Invertébrés, Institut National de la Recherche Agronomique, B.P. 2078, 06606 Antibes Cedex, France

Maria Joao Gravato-Nobre ${ }^{2}$

Unidade de Ciências e Tecnologias Agrárias, Universidade do Algarve, Campus de Gambelas, Algarve, 8000 Faro, Portugal

Antonio Felipe ${ }^{3}$

Servicio de Investigación Agraria, Apartado 727, 50080 Zaragoza, Spain

Additional index words. root-knot nematodes, peach, peach-almond hybrid, plum, salinity

Abstract. The influence of salinity and plant age on nematode reproduction was determined on two susceptible and six root-knot-nematode-resistant Prunus rootstocks inoculated with Meloidogyne incognita (Kofoid and White). Experiments were conducted under greenhouse conditions over 120 (plant age study) and 75 (salinity study) days. Following inoculation with 4000 nematodes per plant, susceptible 2-month-old GF-677 (Prunus persica L. Batsch. X P. dulcis Mill. Webb) and Montclar (P. persica) were affected significantly more than 1-year-old plants. Barrier (P. persica $\times$ P.davidiana Carr. Franch.) plantlets showed a partial loss of resistance in relation to older plants, suggesting that a root tissue maturation period is required for expression of full resistance. Nemared $(P$. persica); G X N No 22 (P. persica X P. dulcis); and the plums GF 8-1 (P. cerasifera Ehrh. X $P$. munsoniana Wight and Hedrick), PSM 101 (P. insititia L.), and P 2980 (P. cerasifera) maintained their high level of resistance or immunity, regardless of plant age. Nematode reproduction was higher in GF-677 rootstock in saline soil. Nemared and Barrier showed similar low galling and nematode reproduction in nonsaline and saline soil. PSM 101 immunity to $M$. incognita was not affected by soil condition.

Screening and resistance verification procedures against root-knot nematodes in Prunus rootstock selection involve repeated testing of plant material with single nematode populations (Esmenjaud et al., 1994; Marull et al., 1991) and mixtures of populations involving several Meloidogyne species to ensure broad resistance (Marull et al., 1994; Scotto la Massese et al., 1984). Plant material found to be resistant after screening and verification should be challenged with additional stress evaluations that may modify the expression of resistance affecting plant defense mechanisms (Canto-Saenz, 1985; Rohde, 1972). Temperature, nutritional status, soil $\mathrm{pH}$, salinity, and

Received for publication 18 Nov. 1994. Accepted for publication 17 Feb. 1995. This work was financed by the Spanish Instituto Nacional de Investigaciones Agrarias grant SC92-132 and the Commission of European Communities Agriculture and Agroindustrial Research Contract 920312. The cost of publishing this paper was defrayed in part by the payment of page charges. Under postal regulations, this paper therefore must be hereby marked advertisement solely to indicate this fact. ${ }^{1}$ Graduate Assistant.

${ }^{2}$ Research Nematologist.

${ }^{3}$ Plant Breeder. plant age are some of the abiotic factors that may alter resistance expression to nematodeinfected plants (Canals et al., 1992; Davide and Triantaphyllou, 1967; Heald and Heilman, 1971; Jaffee and Mai, 1979; Mashela et al., 1992; Sarah et al., 1991; Wehunt, 1972). Thus, even without taking into account the pathogenic variability of the nematode, the assessment of resistance in supposedly resistant plant material should include additional testing to ensure that nematode resistance will be maintained under environmental and physiological stress conditions.

Our purpose was to determine the influence of salinity and plant age on the expression of resistance to $M$. incognita in eight Prunus rootstocks. Most of the tested materials were advanced breeding lines or commercial rootstocks developed for root-knot-nematode resistance and recently introduced into southern Europe.

\section{Materials and Methods}

Seeds, herbaceous cuttings, and micropropagated material were supplied by public research institutes and private sources from Spain and France (Table 1). Seeds of the peach rootstocks Nemared and Montclar were treated with a 5\% solution of copper oxychloride for $24 \mathrm{~h}$, rinsed in water, and stratified in perlite on trays that were kept in a storage room at $4 \mathrm{C}$ for 90 days. Then the seeds were moved to a $25 \pm$ $5 \mathrm{C}$ greenhouse to induce germination. Herbaceous cuttings of the peach-almond hybrid G $x$ N No 22 were treated for $10 \mathrm{sec}$ with a $50 \%$ alcohol solution that contained $2000 \mathrm{ppm}$ of indole butyric acid (Hansen and Hartman, 1968). Cuttings were planted in small pots $\left(300 \mathrm{~cm}^{3}\right)$ containing a pasteurized (70C) 3 sand : 1 peat mixture $(\mathrm{v} / \mathrm{v})$. The micropropagated peach-almond hybrid GF-677, Barrier peach, and plums PSM 101 and GF 8-1 were received as plantlets from Agromillora Catalana S.A., Sant Sadurní d' Anoia, Barcelona, Spain. The plantlets were transferred from agar to $50-\mathrm{cm}^{3}$ minipots with peat substrate and were climatized in a highhumidity chamber for 14 days. The micropropagated plum P 2980 was supplied from the Fruit Breeding Station of the Institut National de la Recherche Agronomique, Bordeaux, France.

The nematode inoculum consisted of a mixture of five isolates of $M$. incognita to ensure pathogenic diversity for testing (Fernández et al., 1994; Marull et al., 1994). Isolates were originally collected from different hosts and geographical localities (Table 2). Isolates were increased on tomato (Lycopersicon esculentum Mill., 'Redondo Liso') from

Table 1. Source of eight Prunus rootstocks and selections evaluated against Meloidogyne incognita.

\begin{tabular}{|c|c|c|}
\hline Rootstock & Species/selection & Source $^{z}$ \\
\hline$\overline{\text { GF-677 }}$ & $\begin{array}{l}\text { Natural peach- } \\
\text { almond hybrid }\end{array}$ & INRA, France \\
\hline G x N No 22 & $\begin{array}{l}\text { P. persica } \mathrm{X} \\
\text { P. dulcis }\end{array}$ & SIA, Spain \\
\hline Barrier & $\begin{array}{l}\text { P. persica } \mathrm{x} \\
\text { P. davidiana }\end{array}$ & CNR, Italy \\
\hline & P. persica & USDA, USA \\
\hline & P. per & INRA, Fran \\
\hline GF $8-1$ & $\begin{array}{l}\text { P. cerasifera } \mathrm{X} \\
\text { P. munsoniana }\end{array}$ & INRA, Fran \\
\hline Р 298 & P. cerasifera & INRA, Franc \\
\hline PSM-101 & P. insititia & CSIC, Spain \\
\hline
\end{tabular}

$\overline{{ }^{2} \text { INRA }=\text { Institut National de la Recherche }}$ Agronomique; SIA = Servicio de Investigación Agraria; CNR = Centro Nazionale della Recerca; USDA = U.S. Dept. of Agriculture; $\mathrm{CSIC}=$ Consejo Superior de Investigaciones Científicas.

Table 2. Host and geographic origin of the five Meloidogyne incognita isolates used for testing Prunus rootstocks.

\begin{tabular}{|c|c|c|}
\hline$\overline{\text { Isolate }^{z}}$ & Host & Geographic origin \\
\hline$\overline{\mathrm{Mi} \text { VR-ES }}$ & $\begin{array}{l}\text { Peach-almond } \\
\text { hybrid }\end{array}$ & $\begin{array}{l}\text { Villaverde del Río, } \\
\text { Seville, Spain }\end{array}$ \\
\hline Mi AN-ES & Plum & $\begin{array}{l}\text { Andújar, Jaén } \\
\text { Spain }\end{array}$ \\
\hline Mi PR-FR & Tomato & Provence, France \\
\hline Mi NC-US & Tomato & $\begin{array}{l}\text { North Carolina, } \\
\text { USA }\end{array}$ \\
\hline Mi RC-AR & Peach & $\begin{array}{c}\text { Rama Caída, } \\
\text { Mendoza, } \\
\text { Argentina }\end{array}$ \\
\hline
\end{tabular}

 morphic DNA analysis.

HortSCIEnCE, Vol. 30(3), June 1995 
single egg-mass cultures. Nematodes were identified by perineal patterns ( 20 females per population) and confirmed by random amplified polymorphic DNA analysis (Cenis, 1993).

Plant age study. Plant material for this study was prepared in 2 years. One-year-old plant material was propagated in year $1 ; 2$ month-old plant material of the same rootstocks was prepared in year 2. In both cases, plantlets were transplanted to 3 -liter pots containing a pasteurized sandy loam textured soil (76\% sand, $14 \%$ silt, $1 \%$ clay; $\mathrm{pH} 7.5 ;<1 \%$ organic matter; and a cation exchange capacity $<10 \mathrm{meq} / 100 \mathrm{~g}$ soil).

Two age-related experiments were established. In the first one, 2- (young) and 12-(old) month-old GF-677, Nemared, and GF 8-1 rootstocks were inoculated with $M$. incognita. In the second experiment, young and old Montclar, G x N No 22, Barrier, PSM 101, and P 2980 rootstocks were evaluated against the same nematode species. Nematode inoculum was prepared by macerating infested tomato roots infected with each isolate in $0.12 \%$ to $0.15 \% \mathrm{NaOCl}$ solution separately for $15 \mathrm{sec}$ in a blender (Hussey and Barker, 1973). Eggs and juveniles were collected using a 25 $\mu \mathrm{m}$-pore sieve (500 mesh) and rinsed with tap water. Before inoculation, a mixture of the five isolates in equal proportion was prepared. Inoculum was adjusted to deliver a suspension of 4000 nematodes per plant through four 3 - to 4-cm-deep holes in the medium located $3 \mathrm{~cm}$ from the base of the plant.

The total number of root galls, final nematode population per plant, and the number of nematodes per gram of root in 2- and 12month-old plants were assessed 120 days after inoculation. Nematodes in soil were recovered by removing soil from containers and placing it in a large pan. Roots were washed free of soil particles in a second pan with a known volume of water. Contents of both pans were mixed and stirred for $1 \mathrm{~min}$. A $250-\mathrm{cm}^{3}$ subsample of the slurry was obtained, and nematodes were extracted by differential sieving and sugar flotation (Jenkins, 1964).

Nematode extraction from roots was similar to that used for inoculum preparation. However, extra time $(30 \mathrm{sec})$ was used to macerate the roots to break-up lignified elements present in rootstocks to free eggs and second-stage juveniles embedded in the root tissue. Nematodes were concentrated using 150-, 74-, and $25-\mu \mathrm{m}$ pore sieves $(100,200$, and 500 mesh, respectively). Root tissue and debris collected on the $150-\mu \mathrm{m}$ sieves were discarded.

Resistance (modified Taylor and Sasser, 1978) was rated based on galling and nematode reproduction: $\mathrm{I}=$ immunity (absence of galling, no nematode penetration or reproduction); HR = highly resistant (nematode invades root but there is little or no reproduction, normally no galling); $\mathrm{R}=$ resistant (limited reproduction with final nematode population lower than initial, incipient galling); MR = moderately resistant (final population lower than initial, low galling, although noticeable); $\mathrm{S}=$ susceptible (nematode reproduces well in a short period, with abundant galling and egg masses in the roots).
During both plant age experiments, the air mean in the greenhouse fluctuated between 15 and $34.5 \mathrm{C}$. Plants were watered daily, or as needed, and fertilized with a full-strength Hoagland's nutrient solution once a week (Hoagland and Arnon, 1950).

Salinity study. Fifteen 2- to 3-month-old plants each of GF-677, Nemared, Barrier, and PSM 101 and with uniform growth were transplanted into conical $220-\mathrm{cm}^{3}$ potting trays (20 $\mathrm{cm}$ deep) that contained a pasteurized sandy loam soil ( $77 \%$ sand, $18 \%$ silt, $5 \%$ clay), electrical conductivity $\left(\mathrm{EC}_{25}\right) 0.204 \mathrm{dS} \cdot \mathrm{m}^{-1}$,

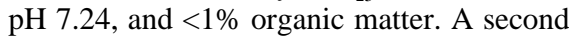
set of the same rootstocks were transplanted to a saline soil obtained from Amposta, Delta del Ebro, Tarragona, Spain. Previously, this soil had been pasteurized and mixed with quartz sand at 2 soil : 1 sand $(\mathrm{v} / \mathrm{v})$ to reduce the initial salinity levels $\left(\mathrm{EC}_{25} 3.0\right.$ to $\left.4.0 \mathrm{dS} \cdot \mathrm{m}^{-1}\right)$, which were phytotoxic to Nemared and Barrier. The soil mixture contained $65 \%$ sand, $25 \%$ silt, $10 \%$ clay and had the following properties: $\mathrm{EC}_{25} 2.037 \mathrm{dS} \cdot \mathrm{m}^{-1}, \mathrm{pH} 7.64$, and $<1 \%$ organic matter. One week after transplanting, both sets of plants were inoculated with the same mixture of isolates used in the age experiments (4000 M. incognita per plant).

Salinity level was maintained throughout the experiment (13 weeks) by periodically adding a $0.1-\mathrm{M} \mathrm{NaCl}$ solution. Plants in nonsaline soil were irrigated with distilled water as needed. Every 10 days, $\mathrm{EC}_{25}$ of the water leachate was measured in saline and

Table 3. Response of GF-677 (susceptible), Nemared, and GF 8-1 (resistant) rootstocks of two ages inoculated with 4000 Meloidogyne incognita per plant, evaluated 120 days after inoculation.

\begin{tabular}{|c|c|c|c|c|c|}
\hline Rootstock & $\begin{array}{c}\text { Plant } \\
\text { age } \\
\text { (months) }\end{array}$ & $\begin{array}{l}\text { No. galls/ } \\
\text { plant }\end{array}$ & $\begin{array}{c}\text { Final nematode } \\
\text { population } \\
\text { (soil and roots) }^{\mathrm{z}}\end{array}$ & $\begin{array}{c}\text { Nematodes/ } \\
\mathrm{g} \text { of root }\end{array}$ & $\begin{array}{l}\text { Resistance } \\
\text { rating }\end{array}$ \\
\hline \multirow[t]{2}{*}{$\overline{\text { GF-677 }}$} & 2 & $200 a^{x}$ & $30,750 \mathrm{a}$ & $3,570 \mathrm{a}$ & $\mathrm{S}$ \\
\hline & 12 & $115 \mathrm{~b}$ & $10,010 \mathrm{~b}$ & $1,870 \mathrm{~b}$ & $\mathrm{~S}$ \\
\hline \multirow[t]{2}{*}{ Nemared } & 2 & $8 \mathrm{a}$ & $38 \mathrm{a}$ & $4 \mathrm{a}$ & HR \\
\hline & 12 & $3 \mathrm{a}$ & $50 \mathrm{a}$ & $1 \mathrm{a}$ & HR \\
\hline \multirow[t]{2}{*}{ GF 8-1 } & 2 & $0 \mathrm{a}$ & $0 \mathrm{a}$ & $0 \mathrm{a}$ & I \\
\hline & 12 & $0 \mathrm{a}$ & $0 \mathrm{a}$ & $0 \mathrm{a}$ & I \\
\hline
\end{tabular}

zTotal number of nematodes per plant.

${ }^{\text {y }} \mathrm{S}=$ susceptible; $\mathrm{HR}=$ highly resistant; $\mathrm{I}=$ immune.

${ }^{x}$ Data are means of 10 replications. Arithmetic means are presented, but data were transformed to $\log _{10}(\mathrm{x}$ +1 ) for analysis. Separation of paired means in columns within each rootstock by Student's $t$ test $(P \leq 0.05)$.

Table 4. Response of Montclar (susceptible) and G x N No 22, Barrier, PSM 101, and P 2980 (resistant) rootstocks of different ages inoculated with 4000 Meloidogyne incognita per plant, evaluated 120 days after inoculation.

\begin{tabular}{|c|c|c|c|c|c|}
\hline Rootstock & $\begin{array}{c}\text { Plant } \\
\text { age } \\
\text { (months) }\end{array}$ & $\begin{array}{c}\text { No. galls/ } \\
\text { plant }\end{array}$ & $\begin{array}{c}\text { Final nematode } \\
\text { population } \\
\text { (soil and roots) }^{z}\end{array}$ & $\begin{array}{c}\text { Nematodes/ } \\
\text { g of root }\end{array}$ & $\begin{array}{c}\text { Resistance } \\
\text { rating }^{\mathrm{y}}\end{array}$ \\
\hline \multirow[t]{2}{*}{ Montclar } & 2 & $158 a^{x}$ & $10,650 \mathrm{a}$ & $690 \mathrm{a}$ & $\mathrm{S}$ \\
\hline & 12 & $25 \mathrm{~b}$ & $3,480 \mathrm{~b}$ & $1,020 \mathrm{a}$ & $\mathrm{S}$ \\
\hline \multirow[t]{2}{*}{$\mathrm{G} \times \mathrm{N}$ No 22} & 2 & $1 \mathrm{a}$ & $213 \mathrm{a}$ & $25 \mathrm{a}$ & HR \\
\hline & 12 & $0 \mathrm{a}$ & $77 \mathrm{a}$ & $9 \mathrm{a}$ & HR \\
\hline \multirow[t]{2}{*}{ Barrier } & 2 & $90 \mathrm{a}$ & $509 \mathrm{a}$ & $120 \mathrm{a}$ & MR \\
\hline & 12 & $21 \mathrm{~b}$ & $93 \mathrm{~b}$ & $13 \mathrm{~b}$ & $\mathrm{R}$ \\
\hline \multirow[t]{2}{*}{ PSM 101} & 2 & $0 \mathrm{a}$ & $0 \mathrm{a}$ & $0 \mathrm{a}$ & I \\
\hline & 12 & $0 \mathrm{a}$ & $0 \mathrm{a}$ & $0 \mathrm{a}$ & I \\
\hline \multirow[t]{2}{*}{ P 2980} & 2 & $0 \mathrm{a}$ & $0 \mathrm{a}$ & $0 \mathrm{a}$ & I \\
\hline & 12 & $0 \mathrm{a}$ & $0 \mathrm{a}$ & $0 \mathrm{a}$ & I \\
\hline
\end{tabular}

${ }^{\mathrm{z}}$ Total number of nematodes per plant.

${ }^{y} \mathrm{~S}=$ susceptible; $\mathrm{MR}=$ moderately resistant; $\mathrm{R}=$ resistant; $\mathrm{HR}=$ highly resistant; $\mathrm{I}=$ immune.

Data are means of 12 replications. Arithmetic means are presented, but data were transformed to $\log _{10}(\mathrm{x}$

+1 ) for analysis. Separations of paired means in columns within each rootstock by Student's $t$ test $(P \leq 0.05)$. 
nematodes were found in the roots or soil in GF 8-1, indicating an immune response. Galls of Nemared were small ( 0.5 to $2 \mathrm{~mm}$ in diameter) with no visible egg mass, whereas those of GF-677 were considerably larger ( 2 to $8 \mathrm{~mm}$ in diameter) and had easily visible whitecolored egg masses under the dissecting microscope. In the second experiment, the susceptible peach Montclar showed a pattern similar to that of GF-677 (Table 4). Two-monthold plants had higher galling and a greater final nematode population than 1-year-old trees but with no differences in the number of nematodes per gram of root. The peach-almond hybrid G x N No 22 showed the same highly resistant response for young and old plants, whereas 2-month-old Barrier had significantly more galls and a higher level of parasitism (final population and nematodes per gram of root) than older plants. Galls in Barrier were similar in size to those of Nemared ( 0.5 to 2 $\mathrm{mm}$ in diameter), although more abundant. Egg masses were not detected under a dissecting microscope, but eggs were more abundant in the root tissues of Barrier (120 nematodes per gram of root) than in Nemared (four nematodes per gram of root). PSM 101 and P 2980 plums were immune to nematodes at both ages.

Salinity study. Salinity fluctuated throughout the experiment but more for the low saline than the nonsaline soil (Fig. 1). Although a similar level of galling was found in susceptible GF-677 rootstock in nonsaline and saline soil 75 days after inoculation, nematode reproduction was significantly higher in the saline soil (Table 5). Nemared showed minimal galling and low nematode reproduction, maintaining a high level of resistance under both soil conditions. Barrier also showed minimal galling and population buildup, although galling and final population were significantly higher in the nonsaline than in saline soil. PSM 101 showed the same immune response to nematodes in both soils.

\section{Discussion}

Our findings show that the age of plant material affects resistance expression in some Prunus rootstocks resistant to root-knot nematodes. Two-month-old Barrier peach was moderately resistant to $M$. incognita, but the same plant material at 12 months old was resistant. We do not know how this partial loss of resistance might affect the rootstock in terms of field performance. Apparently, this resistant genotype requires physiological maturation of the root tissues before expressing full resistance against the nematode. The mechanisms involved in the delayed expression are unknown. A similar differential response was reported by Canals et al. (1992) with young peach-almond hybrid plantlets infected with M. javanica (Treub) Chitwood. They found that the resistance of $\mathrm{G} \times \mathrm{N}$ No 1 could be severely affected by root-knot nematode attack in its initial stages of growth, which, however, would be less damaging or completely resistant after the first year of growth. This difference did not exist in our study with
$\mathrm{G} \times \mathrm{N}$ No 22, a sister breeding line of $\mathrm{G} \times \mathrm{N}$ No 1 , although both selections were evaluated under similar experimental conditions. $\mathrm{G} \times \mathrm{N}$ No 22, which is also more tolerant to calcareous soils than $\mathrm{G} \times \mathrm{N}$ No 1 (Fernández et al., 1993), seems to have inherited the stable resistance of its male parent, Nemared peach (Ramming and Tanner, 1983).

It is noteworthy that older plants of susceptible GF-677 and Montclar showed a tendency to gall less than the young ones. Also, nematode reproduction in these rootstocks was about one-third that for 2-month-old plants, indicating greater susceptibility in young, less suberized, and less lignified root tissues (Wilson and Petersen, 1983).

Although Mashela et al. (1992) showed that salinity affects resistance against nematodes in other perennial crops, salinity does not seem to be an important factor affecting root-knot nematode resistance in Prunus rootstocks. Salinity had little or no effect over the expression of resistance in Nemared, Barrier, and PSM 101 rootstocks inoculated with $M$. incognita. However, soil salinity, although low $\left(\mathrm{EC}_{25} 1.67\right.$ to $\left.2.21 \mathrm{dS} \cdot \mathrm{m}^{-1}\right)$, did favor nematode reproduction in GF-677. In contrast, Barrier showed greater galling and nematode reproduction in nonsaline soil. Although Barrier was slightly more parasitized in such soil, we did not consider this reaction to be important because nematode reproduction was low. Also, the lower galling and nematode reproduction recorded in GF-677 was probably due to the shorter length of the salinity experiment ( 75 days), allowing not more than two generations of nematodes (30 to 35 days per reproductive cycle) and thus the difficulty in establishing an accurate resistance rating for this rootstock. This shorter evaluation period was due to phytotoxic leaf symptoms in the saline treatment for Nemared, Barrier, and GF-677, which appeared between 40 and 60 days after establishment of the experiment. In a previous experiment, which was discontinued, Nemared and Barrier showed early and severe symptoms of phytotoxicity (Fig. 1) when transplanted to a moderately saline soil $\left(\mathrm{EC}_{25} 3.0\right.$ to $\left.4.0 \mathrm{dS} \cdot \mathrm{m}^{-1}\right)$.

Practical implications of this study could

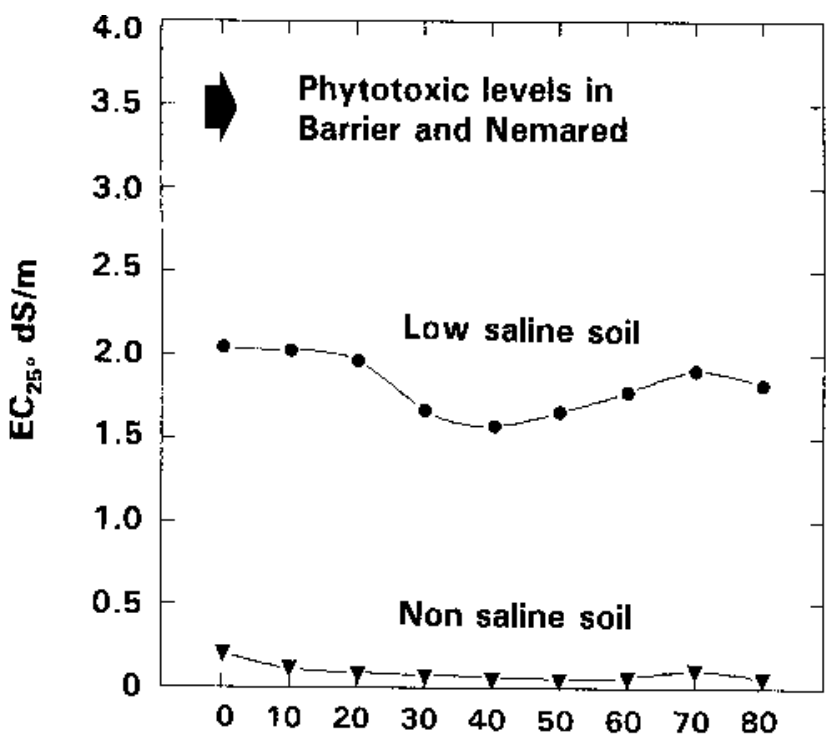

DAYS AFTER INOCULATION

Fig. 1. Fluctuations in conductivity of water extract of low-saline and nonsaline soils in an experiment on the effects of salinity on four Prunus rootstocks inoculated with $M$. incognita.

Table 5. Response of GF-677 (susceptible) and Nemared, Barrier, and PSM 101 (resistant) rootstocks in nonsaline and saline soil inoculated with 4000 Meloidogyne incognita per plant, evaluated 75 days after inoculation.

\begin{tabular}{|c|c|c|c|c|c|}
\hline Rootstock & $\begin{array}{c}\text { Soil } \\
\text { salinity }\end{array}$ & $\begin{array}{c}\text { No. galls/ } \\
\text { plant }\end{array}$ & $\begin{array}{c}\text { Final nematode } \\
\text { population } \\
\text { (soil and roots) }^{\mathrm{z}}\end{array}$ & $\begin{array}{c}\text { Nematodes/ } \\
\text { g of root }\end{array}$ & $\begin{array}{c}\text { Resistance } \\
\text { rating }^{\mathrm{y}}\end{array}$ \\
\hline \multirow[t]{2}{*}{ GF-677 } & Nonsaline & $39 \mathrm{a}^{\mathrm{x}}$ & $960 \mathrm{a}$ & $360 \mathrm{a}$ & MR \\
\hline & Saline & $33 \mathrm{a}$ & $1960 \mathrm{~b}$ & $1360 \mathrm{~b}$ & $\mathrm{~S}$ \\
\hline \multirow[t]{2}{*}{ Nemared } & Nonsaline & $4 \mathrm{a}$ & $20 \mathrm{a}$ & $12 \mathrm{a}$ & HR \\
\hline & Saline & $3 a$ & $38 \mathrm{a}$ & $51 \mathrm{a}$ & HR \\
\hline \multirow[t]{2}{*}{ Barrier } & Nonsaline & $7 \mathrm{~b}$ & $63 \mathrm{~b}$ & $32 \mathrm{a}$ & HR \\
\hline & Saline & $3 a$ & $24 \mathrm{a}$ & $38 \mathrm{a}$ & HR \\
\hline \multirow[t]{2}{*}{ PSM 101} & Nonsaline & $0 \mathrm{a}$ & $0 \mathrm{a}$ & $0 \mathrm{a}$ & I \\
\hline & Saline & $0 \mathrm{a}$ & $0 \mathrm{a}$ & $0 \mathrm{a}$ & I \\
\hline
\end{tabular}

${ }^{2}$ Total number of nematodes per plant.

${ }^{y} \mathrm{~S}=$ susceptible; $\mathrm{MR}=$ moderately resistant; HR = highly resistant; $\mathrm{I}=$ immune.

${ }^{x}$ Data are means of 15 replications. Arithmetic means are presented, but data were transformed to $\log _{10}(\mathrm{x}$

+1 ) for analysis. Separation of paired means in columns within each rootstock by Student's $t$ test $(P \leq 0.05)$. 
be important because young ( 2 to 6 months old) and supposedly resistant rootstocks, such as Barrier, established in root-knot-infested fields could lose resistance. Vulnerability of young plants could be compounded by high temperatures that prevail in southern Europe during the warm season-another important factor also known to modify the expression of resistance in some Prunus rootstocks, mainly peach (Wehunt, 1972) and peach-almond hybrids (Canals et al., 1992; Fernández et al., 1993). Another important practical implication is that young plantlets might not be the ideal material to use for screening against root-knot nematodes because resistant genotypes might be classified as susceptible due to the lack of full resistance expression in early stages of plant development. This eventuality might be especially applicable to peach and peach-almond hybrids that show a delayed expression of resistance against Meloidogyne but not for apricots and plums that show immunity.

\section{Literature Cited}

Canals, J., J. Pinochet, and A. Felipe. 1992. Influence of temperature and age of plant material on the expression of resistance in peach-almond hybrid rootstock infected with Meloidogyne javanica. HortScience 27:1211-1213.

Canto-Saenz, M. 1985. The nature of resistance to Meloidogyne incognita (Kofoid and White, 1919) Chitwood, 1949, p. 255-231. In: J.N. Sasser and C.C. Carter (eds.). An advanced treatise on Meloidogyne. vol. I. Biology and control. North Carolina State Univ. Graphics, Raleigh.

Cenis, J.L. 1993. Identification of four major Meloidogyne spp. by random amplified polymorphic DNA (RAPD-PCR). Phytopathology 83:76-78.
Davide, R.G. and G. Triantaphyllou. 1967. Influence of the environment on development and sex differentiation of root-knot nematodes. I. Effect of infection density, age of the host plant and soil temperature. Nematologica 13:102-110.

Esmenjaud, D., J.C. Minot, R. Voisin, J. Pinochet, and G. Salesses. 1994. Inter- and intraspecific variability in plum, peach, and peach-almond rootstocks using 22 root-knot nematode populations. J. Amer. Soc. Hort. Sci. 119:94-100.

Fernández, C., J. Pinochet, and A. Felipe. 1993. Influence of temperature on the expression of resistance in six Prunus rootstocks infected with Meloidogyne incognita. Nematropica 24:185202.

Fernández, C., J. Pinochet, D. Esmenjaud, G. Salesses, and A. Felipe. 1994. Resistance among new Prunus rootstocks and selections to rootknot nematodes in Spain and France. HortScience 29:1064-1067.

Hansen, C. and H. Hartman. 1968. The use of indolebutyric acid and captan in the propagation of clonal peach and peach-almond hybrid rootstocks by hardwood cuttings. Proc. Amer. Soc. Hort. Sci. 92:135-140.

Heald, C.M. and M.D. Heilman. 1971. Interaction of Rotylenchus reniformis, soil salinity, and cotton. J. Nematol. 2:179-182.

Hoagland, D. and D.I. Arnon. 1950. The water culture method for growing plants without soil. California Agricultural Expt. Station Circ. 347. Univ. of California, Berkeley.

Hussey, R.S. and K.R. Barker. 1973. A comparison of methods of collecting inocula of Meloidogyne spp. including a new technique. Plant Dis. Rptr. 57:1025-1028.

Jaffee, B.A. and W.F. Mai. 1979. Growth reduction of apple seedlings by Pratylenchus penetrans as influenced by seedling age at inoculation. J. Nematol. 11:161-165.

Jenkins, W.R. 1964. A rapid centrifugal floatation technique for separating nematodes from soil. Plant Dis. Rptr. 48:692.
Mashela, P., L. Duncan, and R. McSorley. 1992. Salinity reduces resistance to Tylenchulus semipenetransin Citrus rootstocks. Nematropica 22:7-12.

Marull, J., J. Pinochet, A. Felipe, and J.L. Cenis. 1994. Resistance verification in Prunus selections to a mixture of 13 Meloidogyne isolates and resistance mechanisms of a peach-almond hybrid to M. javanica. Fund. Appl. Nematol. 17:85-92.

Marull, J., J. Pinochet, S. Verdejo, and A. Soler. 1991. Reaction of Prunus rootstocks to Meloidogyne incognita and M. arenaria in Spain. J. Nematol. 23:564-569.

Porta, J. 1986. Técnicas y Experimentos en Edafología. Col.legi Oficial d'Enginyers Agrònoms de Catalunya.

Ramming, D.W. and O. Tanner. 1983. Nemared peach rootstock. HortScience 18:376.

Rohde, R.A. 1972. Expression of resistance in plants to nematodes. Annu. Rev. Phytopathol. 10:233251.

Sarah, J.L., B. Osseni, and R. Hugon. 1991. Effect of soil $\mathrm{pH}$ on development of Pratylenchus brachyurus in pineapple roots. Nematropica 21:211-216

Scotto La Massese, C., C.H. Grasselly, J.C. Minot, and R. Voisin. 1984. Différence de comportament de 23 clones et hybrides de Prunus à l'égard de quatre espèces de Meloidogyne. Revue de Nématologie 7:265-270.

Taylor, A.L. and J.N. Sasser. 1978. Biology, identification and control of root-knot nematodes (Meloidogyne species). North Carolina State Univ. Graphics, Raleigh.

Wehunt, E.J. 1972. Influence of temperature on infection of Meloidogyne incognita acrita on Nemaguard peach. Plant Dis. Rptr. 56:305308.

Wilson, C.A. and C.A. Peterson. 1983. Chemical composition of the epidermal, hypodermal and intervening cortical cell walls of various plant roots. Ann. Bot. 51:759-769. 